\title{
TRANSMISSION OF FINANCIAL STRESS SHOCKS BETWEEN THE USA AND THE EURO AREA DURING DIFFERENT BUSINESS CYCLE PHASES
}

\section{Silvo Dajčman', Alenka Kavkler², Peter Mikek³, Dejan Romih ${ }^{4}$}

\footnotetext{
1 University of Maribor, Faculty of Economics and Business, Department of Economic Policy, Slovenia, silvo.dajcman@um.si;

2 University of Maribor, Faculty of Economics and Business, Department of Quantitative Economic Analysis, Slovenia, alenka.kavkler@um.si;

3 Wabash College, Department of Economics, United States of America, mikekp@wabash.edu;

4 University of Maribor, Faculty of Economics and Business, Department of International Economics and Business, Slovenia, ORCID: 0000-0001-9123-0183, dejan.romih@um.si;
}

\begin{abstract}
This paper examines the transmission of financial stress shocks between the USA and the euro area for recessionary and non-recessionary regimes in the shock-recipient economy. The investigated period is 1999M1-2017M11, which includes several episodes of recessionary and non-recessionary regimes, endogenously determined by the model, as well as several financial stress episodes. After testing for non-linearity, we employ a five-variable Bayesian threshold vector autoregression model using internationally compatible data for financial stress indices. Our results show significant non-linearities in the financial stress-business cycle interactions for the euro area. In comparison to the non-recessionary regime, the US financial stress shocks are more detrimental to the stability of the European financial system, output growth, and inflation in recessions. US financial stress shocks negatively affect euro area unemployment rate, but the effect is independent of the euro area industrial production growth regime. In contrast, the stability of the US financial system is not susceptible to the euro area's financial stress shocks. However, due to trade ties, the financial stress in the euro area does lead to output contraction, while not affecting inflation and unemployment in the US. We also found that US industrial production growth and unemployment rate are susceptible to domestic financial stress shocks, more in the recessionary than nonrecessionary episodes of the US economy. The results suggest a need for a careful domestic and foreign financial stress monitoring and coordination of monetary authorities. While this may profit both economic areas, this is relevant more for the European Central Bank than its US counterpart.
\end{abstract}

Keywords: Financial stress, international transmission of financial stress, business and financial cycles, nonlinearity, threshold VAR.

JEL Classification: E32, E44, G01.

APA Style Citation: Dajčman, S., Kavkler, A., Mikek, P., \& Romih, D. (2020). Transmission of Financial Stress Shocks between the USA and the Euro Area During Different Business Cycle Phases. E\&M Economics and Management, 23(4), 152-165. https://doi.org/10.15240/ tul/001/2020-4-010

\section{Introduction}

After the global financial crisis and the Great Recession, a large and growing body of literature has examined real business-financial cycle linkages. To this end, Claessens et al.
(2012) examined a large database of business and financial stress periods, corroborating that financial crisis periods are often longer and deeper than economic recessions and tend to amplify and prolong the latter. Our research aims 
to contribute to an understanding of the financial stress-macroeconomy nexus by studying the spillovers of US (euro area) financial stress shocks and their macroeconomic effects (i.e. effects on industrial production, inflation and unemployment) into the euro area (USA). This paper asks whether these effects are contingent on the phase of the business cycle.

Traditionally, domestic and international financial stress-business cycle linkages have been investigated within the linear modelling framework. Recently, the linear framework has been criticized by authors employing nonlinear dynamic stochastic general equilibrium (DSGE) models (Brunnermeier \& Sannikov, 2011; Mittnik \& Semmler, 2012, 2013; Schleer \& Semmler, 2014; Boissay et al., 2013; Chen \& Semmler, 2014) for their limited power to explain the differential macroeconomic effects of financial shocks in different regimes of the economy. This literature contends that under high financial stress or recessionary regimes the economy could function differently than in low financial stress or non-recessionary regimes. It identifies several amplification mechanisms which can switch the economy from one regime to another. Our research builds on the framework of this line of research.

To the best of our knowledge, only Evgenidis and Tsagkanos (2017) and Chen and Semmler (2018) have investigated the regime-dependent macroeconomic effects of the international transmission of financial stress shocks. Both studies used the financial stress index for the USA as a threshold variable and explained how the euro area economy responds to US financial stress shocks, conditional on the US financial stress regime. The literature does not show how financial stress shocks are transmitted between the two major economies, based on the domestic business cycle regime. We assert that an answer to this question is relevant for policymaking and aim to fill this gap in the literature.

Our research also extends the literature that uses the Composite Indicator of Systemic Stress (CISS), constructed by Holló et al. (2012) and maintained by the European Central Bank (ECB). The CISS aggregates various stress indicators of five major segments of the financial system (financial intermediaries, money markets, bond markets, equity markets and foreign exchange markets) based on their time-varying co-movements (further details are given in the Appendix). As the latter are stronger when the stress is elevated in several segments of the financial system, this indicator is considered to capture the materialization of systemic risk (Holló et al., 2012; Kremer, 2016a, 2016b). As such, it has a "substantial and robust explanatory power for standard macroeconomic variables" (Kremer, 2016b), as demonstrated in various research applications (e.g. Holló et al., 2012; Kremer, 2016a, 2016b; Adam \& Benecká, 2013).

Furthermore, we complement the existing literature by explicitly including the labour market response to spillovers of a financial stress shock. The literature on the financial-real sector nexus has largely neglected the effect of a financial stress on unemployment. Related literature on the international transmission of uncertainty shocks, however, illustrates that the relationship is non-linear (Morley \& Piger, 2012; Caggiano et al., 2014, 2017). This is due to uncertainty shocks provoking a stronger surge in the unemployment rate during recessions than in non-recessions.

The empirical research in the paper is based on the Bayesian threshold VAR (TVAR) modelling framework. Recessionary and nonrecessionary regimes during period 1999M1$2017 \mathrm{M} 11$ are determined by the model and then the non-linearity of transmission of international financial stress shocks to macroeconomic variables (industrial production growth, inflation, and unemployment) is studied by generalized impulse responses. The results show significant transmission of US financial stress shocks to euro area, and non-linearities in the transmission.

The remainder of the paper is structured as follows: Section 1 reviews the existing literature, while Section 2 describes the methodology. Section 3 presents the data and empirical results, Section 4 discusses the results and the final section summarizes the main findings.

\section{Literature Review}

One strand in the empirical literature on financial stress-business cycle linkages uses linear vector autoregression (VAR) models to illustrate the destabilizing effects of financial stress shocks on the macroeconomy (e.g. Hakkio \& Keeton, 2009; Gilchrist \& Zakrajsek, 2012; Kremer, 2016a). Another strand in the empirical literature also applies linear modelling to show that financial stress (or stress in some 
segment of the financial system, e.g., the credit market) originating in one country can spill abroad and cause detrimental macroeconomic developments (Helbling et al., 2011; Dovern \& van Roye, 2014; Eickmeier \& Ng, 2015; Ha et al., 2017). Theoretical underpinnings of such empirical modelling of business and financial cycle linkages can be found in financial accelerator models (Bernanke \& Gertler, 1989; Kiyotaki \& Moore, 1997; Gertler et al., 2007; Gertler \& Kiyotaki, 2010).

In financial accelerator models, financial stress shocks exacerbate negative economic developments. The effects, however, are meanreverting. As argued by Schleer and Semmler (2014), this is because the financial-real sector interactions are modelled as linear. In nonlinear DSGE models the amplifying effects of financial stress shocks are asymmetric or regime-dependent: while they are strong and more durable when the economy is under a regime of high financial stress or recession, they are small or insignificant when the financial system or economy is in a non-crisis regime (Brunnermeier \& Sannikov, 2011; Mittnik \& Semmler, 2012, 2013; Schleer \& Semmler, 2014; Hubrich \& Tetlow, 2015).

A key role in the switch from a normal to a crisis regime in non-linear DSGE models is played by banks' balance sheets and various amplification mechanisms. In the model of Brunnermeier and Sannikov (2011), upon an exogenous shock to the financial system, large destabilizing effects and regime shifts (amplification) can be the result of an endogenous response concerning asset prices due to precautionary savings and volatility. Other amplification mechanisms can also be at work, e.g., movements in risk premia and credit spreads (Mittnik \& Semmler, 2012, 2013), interplay between risk premia, credit constraints and extensive deleveraging of borrowers (Chen \& Semmler, 2014), a wealth reducing effect on consumption and investment when asset prices fall, or a "diabolic loop" in the interplay between private borrowers, banks and sovereign debt (Schleer \& Semmler, 2014).

The empirical literature exploring nonlinearities in the dynamic relationship between domestic financial stress and the macroeconomy is relatively thin and, in general, supports the theoretical prediction of nonlinearity. Classical TVAR (Mittnik \& Semmler, 2013; Schleer \& Semmler, 2014; Mittnik \&
Semmler, 2014; Chen \& Semmler, 2014), Bayesian Markov-switching VAR (Aboura \& van Roe, 2017; Hartmann et al., 2013), or Bayesian TVAR (Alessandri \& Mumtaz, 2017; Chatterjee et al., 2017) modelling approaches are applied, while (generalized) impulse responses are computed to infer structural relationships between the variables. Most studies set the financial stress indicator as a threshold variable. However, Mittnik and Semmler (2012) study the effect of financial stress shocks on economic activity during low and high financial stress regimes, whereas Chatterjee et al. (2017) focus on recessionary and non-recessionary regimes. Although most researchers design a parsimonious bivariate model, some authors include up to three additional macroeconomic variables in their model (Alessandri \& Mumtaz, 2017; Hartmann et al., 2013; Chatterjee et al., 2017), including the inflation rate, the monetary policy or short-term interest rate, growth in loans, or growth in the nominal effective exchange rate.

A variety of financial stress indices are used: the IMF Financial Stress Index (Mittnik \& Semmler, 2012, 2013; Chen \& Semmler, 2014), the ZEW Financial Condition Index (Schleer \& Semmler, 2014), the Chicago Fed Financial Conditions Index (Alessandri \& Mumtaz, 2017), the CISS (Hartmann et al., 2013) or selfconstructed indices (Aboura \& van Roye, 2017; Chatterjee et al., 2017).

There are numerous studies that explore the non-linear response in industrial production growth to a financial stress. Across a variety of studied countries, they find an asymmetric response in industrial production growth to a positive shock in financial stress. Mittnik and Semmler (2012) studied major European countries (excluding the UK and France), Mittnik and Semmler (2013) looked at the USA, Germany, Italy and France, Alessandri and Mumtaz (2017) considered the USA, Chatterjee et al. (2017) examined the UK, Aboura and van Roye (2017) investigated France, Chen and Semmler (2014) addressed 15 OECD countries, Schleer and Semmler (2014) reviewed 10 major euro area countries, and Hartmann et al. (2013) approached the euro area as a whole. They overwhelmingly reported a significant, regime-dependent drop in production growth in response to a financial stress shock. In general, the reduction is larger in recessionary or high financial stress regimes. For example, Mittnik 
and Semmler (2013) estimated the response to be 2.5 times stronger and Alessandri and Mumtaz (2017) even reported a sixfold stronger response in the recession/high stress regime in the USA. Additionally, Hartmann et al. (2013) find a negative response in the inflation rate, growth in loans and interest rate for the euro area in a high stress regime.

Beyond the literature on dynamic relationship between domestic financial stress and the broader economy, several channels of international financial stress transmission have been identified, including the trade channel (financial stress shocks are more likely to be transmitted and affect the economic activity of countries that mutually trade more), financial market integration (the capital market and global operation of banks), global shocks, and contagion (see Apostolakis \& Papadopoulos, 2014; Dovern \& van Roye, 2014, and references therein).

As already noted, only Evgenidis and Tsagkanos (2017) and Chen and Semmler (2018) investigate the regime-dependent effects of the international transmission of financial stress shocks. Chen and Semmler (2018) apply a bivariate (the IMF's Financial Stability Index and industrial production growth) global VAR (GVAR) model to investigate the effects of financial stress shocks originating in the USA (as a case of a large country) and Belgium (as a small country) on financial stress and industrial production growth in 15 OECD countries. The impulse responses show that, in a high financial stress regime, a financial stress shock in the USA leads to a statistically significant increase in the domestic financial stress in five countries. This contrasts with only one country for Belgium. Under a high stress regime at home, industrial production decreases significantly only for one country due to a US financial stress shock and none in the case of Belgium. In contrast, under a low stress regime, a financial stress shock in the USA and Belgium significantly increases domestic financial stress indices in all observed countries. However, the responses of domestic industrial production growth are not significant across all countries.

Evgenidis and Tsagkanos (2017) analysed the international transmission of financial stress shocks from the USA to the euro area by specifying a model with several endogenous variables (including industrial production, capital flows, short-term interest rate and financial stress index) and a set of exogenous variables (including proxies for uncertainty in the USA and the euro area, gold prices, stock market prices, commodity prices, and expectations about future inflation). Their results indicate that, under a high financial stress regime in the USA, a positive shock (i.e. increase) to US financial stress is detrimental to the euro area's economic activity, interest rate and financial stress. The responses are not significant under a low stress regime.

Besides the differences noted in the introduction, our paper differs from the studies of Chen and Semmler (2018) and Evgenidis and Tsagkanos (2017) in several other important ways. First, both studies use a financial stress index as the threshold variable. The economies investigated in these studies are thus either in a high or in a low financial stress regime. Following Chatterjee et al. (2018) and Chen and Semmler (2014), the threshold variable in our paper is growth in domestic industrial production. Conditional on the threshold value, the considered economy is thus in either a recessionary (low growth) or a non-recessionary regime. We, thus, can answer different questions to those in the referenced studies. Second, in Chen and Semmler (2018), a bivariate TVAR is applied, while Evgenidis and Tsagkanos (2017) consider several endogenous and exogenous variables. We estimate a five-variable TVAR model in which, as commonly found in the literature, all variables are endogenous. Third, Evgenidis and Tsagkanos (2017) use different financial stress indicators for economies: the St. Louis Fed Financial Stress Index for the USA and the CISS for the euro area. As there are certain differences in the construction of different financial stress indicators (for a review, see Kliesen et al., 2012), we find it important to use indicators constructed by employing the same methodology, especially if the research aims to examine regime-dependent international stress spillovers (shock in foreign financial stress spilling over into domestic financial stress) and the transmission of financial stress shocks. Fourth, while the referenced studies apply a classical TVAR, we resort to Bayesian methods in TVAR estimation and inference, which is advantageous over classical maximum likelihood methods in estimation and inference (impulse response analysis) (see Koop \& Potter, 1999; Kwon, 2003). 


\section{Methodology}

To explore the USA-euro area financial stress spillovers and their regime-contingent macroeconomic effects, we employ a Bayesian TVAR model. As noted by Alessandri and Mumtaz (2017), a TVAR is capable of capturing a structural break associated with financial or economic crises. Another useful feature of the model is that the threshold variable is one of the endogenous variables in the model and that the threshold value which switches the economy from one regime to another is determined by the data and not subjectively by the researcher.

To study the financial stress spillovers from the USA in recessionary and non-recessionary regimes in the euro area, we apply the following two-regime TVAR model (see, e.g., Chen \& Lee, 1995):

$$
X_{t}=\left\{\begin{array}{l}
c_{1}+\sum_{i=1}^{p} A_{1, i} X_{t-i}+e_{1 t} \text { if } z_{t-d} \leq z^{*} \\
c_{2}+\sum_{i=1}^{p} A_{2, i} X_{t-i}+e_{2 t} \text { if } z_{t-d}>z^{*}
\end{array}\right.
$$

where $t=1, \ldots, T, X_{t}=\left[y_{t}^{E A}, u_{t}^{E A}, \pi_{t}^{E A}, \operatorname{ciss}_{t}^{U S}\right.$, $\left.\operatorname{ciss}_{t}^{E A}\right]^{T}$ is a vector of endogenous variables consisting of several domestic (euro area) variables and one foreign (US) variable. In this we follow several recent studies on the effects of international spillovers of uncertainty shocks on macroeconomy (e.g. Caggiano et al., 2017; Fontaine et al., 2017; Huang et al., 2018). The euro area variables included are the annual, i.e., year-on-year, growth in industrial production (see, e.g., Hartmann et al., 2013; Kremer, 2016a) $\left(y_{t}^{E A}\right)$, unemployment rate $\left(u_{t}^{E A}\right)$, annual inflation $\left(\pi_{t}^{E A}\right)$, and (systemic) financial stress level in the euro area ( $\left.c i s s_{t}^{E A}\right)$. The US variable is the US financial stress ( ciss $_{t}^{U S}$ ). $z_{t-d}$ is a threshold variable; $d$ is threshold lag; $z^{*}$ is the unknown threshold value; $c_{1}\left(c_{2}\right.$, respectively) is a regime-specific $5 \times 1$ vector of constants; $p$ is the lag length of the TVAR; $A_{1, i}\left(A_{2, i}\right.$, respectively) is the regime-specific matrix of coefficients for lag $i . e_{1 t}\left(e_{2 t}\right.$, respectively) is a $5 \times 1$ vector of i.i.d. regime-specific errors (see Chen \& Lee, 1995). The threshold variable in (1a), $z_{t-d}$, is the $d$-th lag of $y_{t}^{E A}$.

Financial stress spillovers from the euro area into the USA and their macroeconomic effects in recessionary and non-recessionary regimes of the US economy are studied by an identical model with a slightly different endogenous vector, i.e., $X_{t}$ :

$$
X_{t}=\left\{\begin{array}{l}
c_{1}+\sum_{i=1}^{p} A_{1, i} X_{t-i}+e_{1 t} \text { if } z_{t-d} \leq z^{*} \\
c_{2}+\sum_{i=1}^{p} A_{2, i} X_{t-i}+e_{2 t} \text { if } z_{t-d}>z^{*}
\end{array}\right.
$$

where $X_{t}=\left[y_{t}^{U S}, u_{t}^{U S}, \pi_{t}^{U S}, \operatorname{ciss}_{t}^{U S}, \operatorname{ciss}_{t}^{E A}\right]^{T}$; and $y_{t}^{U S}$, $u_{t}^{U S}$ and $\pi_{t}^{U S}$ refer to annual growth in industrial production, unemployment rate and inflation in the USA. The threshold variable in (1b), $z_{t-d}$, is the $d$-th lag of $y_{t}^{U S}$.

Depending on $z_{t-d}$, the economy described by (1a) and (1b) is thus endogenously labelled as being in a recessionary regime when $z_{t-d} \leq z^{*}$, or in a non-recessionary regime when $\left(z_{t-d}>z^{*}\right)$. Note that this definition of recessions dating may differ from those, e.g., of the NBER and the CEPR, which observe quarterly real GDP growth and several other economic variables in order to identify business cycle turning points. The model is piece-wise (withinregime) linear. Each row of (1a) and (1b) thus describes a regime-specific VAR model. The model, however, is non-linear in time (Chen \& Lee, 1995).

Following the commonly used approach, the lag, $p$, of Models (1a) and (1b) is determined by applying the Akaike information criteria to the linear VAR model (limiting the maximum lag $(p)$ of 12):

$$
X_{t}=c+\sum_{i=1}^{p} A_{i} X_{t-i}+e_{t}
$$

where $X_{t}$ is as defined above for (1a) and (1b), respectively; $c$ is a $5 \times 1$ vector of regression constants; $A_{i}$ is a matrix of coefficients for lag $i$; and $e_{t}$ is a $5 \times 1$ vector of i.i.d. errors.

After determining the lag order, Models (1a) and $(1 \mathrm{~b})$ are estimated by Bayesian methods, applying the approach of Alessandri and Mumtaz (2017) who follow Sims and Zha (1998) and Banbura et al. (2010). More specifically, we use the same normal inverse Wishart prior for estimating the regime-specific VAR parameters. We closely follow Alessandri and Mumtaz (2017) and use the $A R(1)$ estimates for the individual endogenous variables to obtain the priors, means and scaling factors. The overall prior is $\tau=0.1$, while the prior for the constant is set at 0.0001 , and the tightness of the priors in the sum of coefficients is $\lambda=10 \tau$. The prior for the threshold lag is set at a maximum of 4 , while the prior for the threshold value is normally distributed, i.e., $Z^{*} \sim N(\bar{Z}, \bar{s})$, where $\bar{Z}$ is the sample mean of the threshold variable and $\bar{s}$ is the variance in the prior of variable $z_{t}$. 
Conditional on the initial $z^{*}$ and $d$, the conditional posterior distribution of the regime-specific VAR coefficient is normal and the conditional posterior of the variance-covariance matrix is inverse Wishart distributed. The Gibbs sampler of Chen and Lee (1995) with 15,000 iterations and 5,000 burn-ins is used to draw the posterior distributions. The threshold value is drawn from the Metropolis Hastings step. For a more comprehensive description of the settings, refer to Alessandri and Mumtaz (2017).

Dynamic responses from macroeconomic variables to financial stress shocks are explored using the generalized impulse responses, i.e., non-linear impulse response analysis, suggested by Koop et al. (1996). The generalized impulse responses for a regime $R\left(\right.$ IIRF $\left._{t}^{R}\right)$, where $R=$ recessionary, nonrecessionary, are defined as follows (Koop et al., 1996; Alessandri \& Mumtaz, 2017):

$$
\begin{aligned}
& G I R F_{t}^{R}=E\left(X_{t+h} \mid \Phi_{t}, X_{t-1}^{R}, \eta\right)- \\
& -E\left(X_{t+h} \mid \Phi_{t}, X_{t-1}^{R}\right)
\end{aligned}
$$

where $E$ denotes expectation; $h$ is the time horizon; $\Phi_{t}$ are all the parameters of Models (1a) and (1b), respectively; $X_{t-1}^{R}$ is the regime-specific history; and $\eta$ is a shock. Given the parameters of Models (1a) and (1b), respectively, and the regime-specific history, the first term on the right side of (3) is the conditional expectation of the endogenous variable under a shock (a one standard deviation shock concerning the variable of interest), while the second term is the conditional expectation of the endogenous variable with no shock. Empirically, the conditional expectations for a specific regime $R$ are estimated by simulating the model (100 replications) for all possible starting values in that regime. Impulse responses (3) are then computed (by 500 Gibbs iterations) for all histories in the regime. Mean responses and the $68 \%$ confidence interval are finally computed. The computation is performed by the MATLAB codes of Alessandri and Mumtaz (2017). We wish to thank the authors for making their code available.

Structural identification of financial stress shocks is achieved through the Cholesky identification scheme, as is standard in the TVAR literature. Similarly, following the referenced literature, we place the real economic variables $\left(y_{t}^{E A}, u_{t}^{E A}\right)$ and inflation
( $\pi_{t}^{E A}$ ) first, followed by the financial variables $\left(\right.$ ciss $_{t}^{U S}$, ciss $_{t}^{E A}$ ). This implies that the financial variables are contemporaneously affected by real economic variables, but not the reverse. We place US financial stress before that of the euro area, as in Chen and Semmler (2018) and several other studies on the international transmission of shocks from the USA (e.g. Dovern \& van Roye, 2014; Caggiano et al., 2017; Huang et al., 2018). This is in line with the notion of the larger global impact of the US economy and its financial markets as compared to the euro area. This order is also supported graphically (see Fig. 1 in continuation) due to the fact that major financial stress events during the sample period, which originated in the USA, not only elevated financial stress in the USA, but also contemporaneously in the euro area, whereas, during a major stress event in the euro area (the euro debt crisis), this was not the case. By placing $c i s s_{t}^{U S}$ in the penultimate place, we assume that systemic financial stress in the USA is contemporaneously affected by all euro area "real" macroeconomic variables (industrial production, unemployment, inflation), albeit only with a lag regarding the euro area financial stress. By placing $\operatorname{ciss}_{t}^{E A}$ last, we assume that all other variables in the model contemporaneously affect financial stress in the euro area, whereas the euro area's financial stress affects other variables albeit only with a lag.

\section{Data and Empirical Results}

The data consist of monthly observations for the period 1999M1-2017M11, limited at the start by the birth of the euro area and at the end by the availability of data for the variable ciss $_{t}^{U S}$. A detailed description of all variables with statistical summary is contained in Tab. 1.

We can observe that the mean annual growth in industrial production in euro area was slightly (0.02 percentage points) higher but also more volatile than in the USA. Mean unemployment rate in euro area was 3.42 percentage points higher than in the USA, but less volatile, while mean inflation rate in euro area was 0.43 percentage points lower and less volatile than in the USA. CISS in euro area was on average higher and more volatile than in the USA.

The dynamics of and and the recessionary regimes, as determined by (1a) and (1b), are presented in Fig. 1. Cleary, the financial stress in the euro area and in the USA during the 


\begin{tabular}{|c|c|c|c|c|c|}
\hline $\begin{array}{l}\text { Variable } \\
\text { notation }\end{array}$ & Mean & Max & Min & St. dev. & Description \\
\hline$y_{t}^{E A}$ & 0.98 & 9.34 & -21.32 & 4.87 & \multirow{2}{*}{$\begin{array}{l}\text { Annual growth in industrial production (percentage } \\
\text { change compared to the same month in the previous } \\
\text { year) for total industry, excluding construction; monthly } \\
\text { frequency; calculated from the monthly seasonally } \\
\text { adjusted index ( } 2015=100) \text {. Data source is OECD } \\
\text { (2019a). }\end{array}$} \\
\hline$y_{t}^{U S}$ & 0.96 & 8.47 & -15.34 & 4.18 & \\
\hline$u_{t}^{E A}$ & 9.46 & 12.1 & 7.3 & 1.30 & \multirow{2}{*}{$\begin{array}{l}\text { Unemployment rate, seasonally adjusted, } \\
\text { expressed as a percentage of the active population; } \\
\text { monthly frequency. Data source is Eurostat (2019). }\end{array}$} \\
\hline$u_{t}^{U S}$ & 6.02 & 10.0 & 3.8 & 1.76 & \\
\hline$\pi_{t}^{E A}$ & 1.75 & 4.12 & -0.62 & 0.96 & \multirow{2}{*}{$\begin{array}{l}\text { Inflation rate (percentage change compared to } \\
\text { the same month in the previous year); monthly } \\
\text { frequency; calculated from the consumer price } \\
\text { index }(2015=100) \text {. Data source is OECD }(2019 \mathrm{~b}) \text {. }\end{array}$} \\
\hline$\pi_{t}^{U S}$ & 2.18 & 5.6 & -2.1 & 1.28 & \\
\hline $\operatorname{ciss}_{t}^{E A}$ & 0.19 & 0.78 & 0.03 & 0.16 & $\begin{array}{l}\text { The CISS for the euro area. Monthly values are } \\
\text { calculated from weekly values according to the } \\
\text { arithmetic average. The CISS is constructed by } \\
\text { Holló et al. (2012), maintained by the ECB and } \\
\text { computed in several steps. First, three different } \\
\text { financial stress measures for each of five segments } \\
\text { of the financial system (financial intermediaries, } \\
\text { money markets, bond markets, equity markets and } \\
\text { foreign exchange markets) are collected. In the } \\
\text { second step, the data on individual stress measures } \\
\text { are arranged in ascending order, then transformed } \\
\text { into their empirical cumulative distribution function. } \\
\text { After this transformation, } 15 \text { individual stress } \\
\text { factors are distributed in the interval (0.1). Next, } \\
\text { the stress factors for each of the five segments are } \\
\text { aggregated according to the arithmetic average } \\
\text { to obtain five subindices. The final step consists } \\
\text { of aggregating the subindices to a composite } \\
\text { indicator of financial stress (CISS), based on the } \\
\text { subindices' weights (the most weight is carried } \\
\text { by financial intermediaries and equity market } \\
\text { subindices) and time-varying cross-correlations } \\
\text { between the subindices. The obtained CISS } \\
\text { indicator is distributed over the interval (0.1) and } \\
\text { measures the "ex-post systemic stress, i.e. risk that } \\
\text { has materialised already" (Holló et al., 2012). Data } \\
\text { source is ECB (2019). }\end{array}$ \\
\hline $\operatorname{ciss}_{t}^{U S}$ & 0.14 & 0.73 & 0.02 & 0.13 & $\begin{array}{l}\text { The CISS for the USA is measured by the same } \\
\text { methodology as. Whereas as well as a similar } \\
\text { indicator for individual euro area countries is } \\
\text { maintained by the ECB, the CISS for the USA } \\
\text { was calculated by Kremer ( } 2016 \mathrm{~b}) \text {. An extended } \\
\text { time series of with a weekly frequency until } \\
\text { November } 10,2017 \text { was calculated and kindly } \\
\text { shared by Manfred Kremer. Data source is Kremer } \\
(2016 \text { b). }\end{array}$ \\
\hline
\end{tabular}




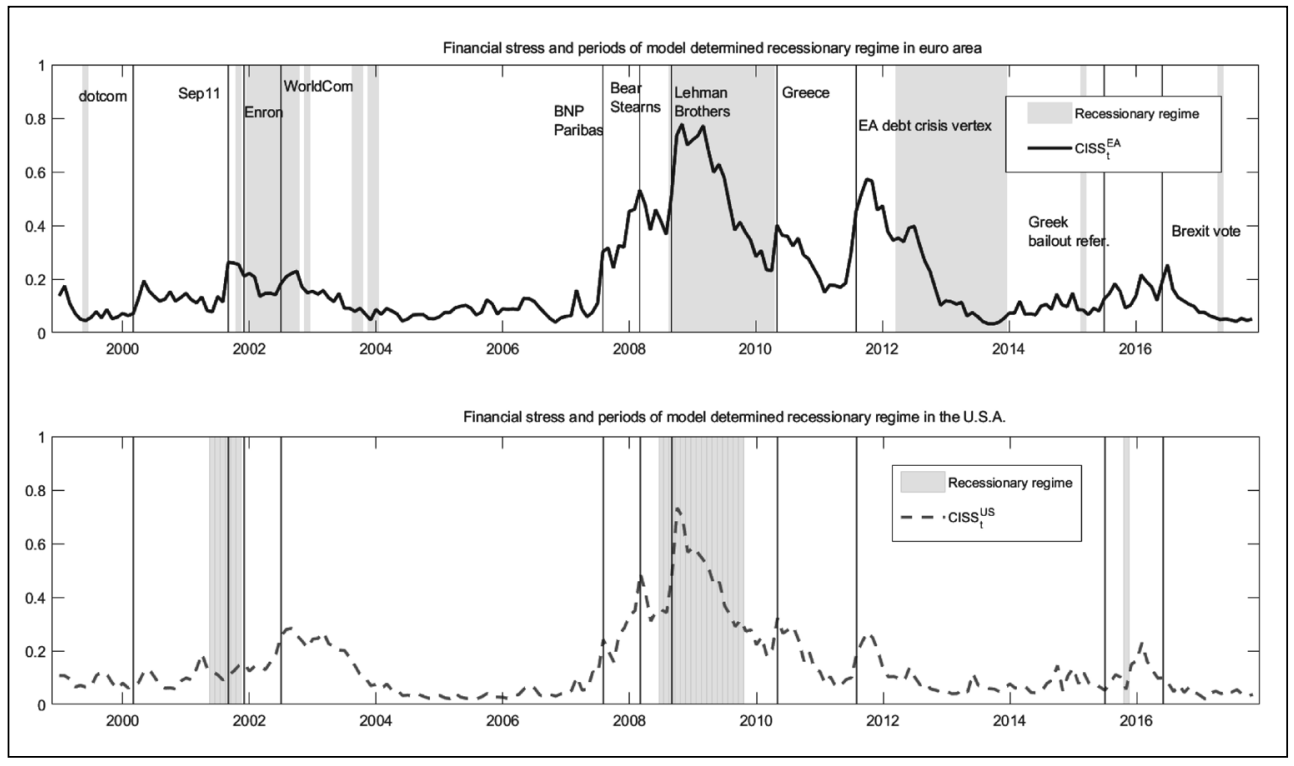

Source: own

Note: Both plots show the financial stress indices for the euro area $\left(\operatorname{ciss}_{t}^{E A}\right)$ and the USA ( $\left.\operatorname{ciss}_{t}^{U S}\right)$ during the period 1999M1-2017M11. The recessionary regimes, determined by (1), are represented by the shaded areas. Major financial stress events in the euro area and the USA are denoted in both plots by vertical lines: burst of the dot-com bubble in March 2000, 9/11 terror attacks (September 2001), Enron bankruptcy (December 2001), WorldCom bankruptcy (July 2002), BNP Paribas (investment fund redemption suspension, August 2007), Bear Sterns collapse (March 2008), Lehman Brothers bankruptcy (September 2008), Greece bailout (May 2010), euro area debt crisis vertex (in August 2011, fear of debt crisis spreading from periphery to the core euro area), Greek bailout referendum (July 2015) and Brexit referendum (June 2016).

observed period is strongly connected (the correlation coefficient is 0.872 ).

The CISS for the euro area and the USA traces out the major events that caused turmoil in the respective financial markets. The largest spikes in the CISS for both areas are associated with the global financial crisis and the euro area sovereign debt crisis. Other important events in the pre-global financial crisis period coincide with the dot-com crisis, the 9/11 terror attacks in the USA, and the Enron and WorldCom bankruptcies. Clearly, the decoupling of the CISS for the two areas is observable during the euro area's sovereign debt crisis, implying that the systemic crisis was limited to the euro area. The financial stress in the euro area decreased in 2013. In the period from 2014 until mid-2016, a tendency of increasing stress is noticeable in both areas. As the ECB (2016) notes, this is related to the Greek bailout referendum in
July 2015, turmoil in the Chinese stock market turmoil, and the uncertainty spurred by the Brexit referendum. In 2017, the CISS in both areas returned to relatively low levels, indicating relative financial stability.

Fig. 1 also presents recessionary regimes in both economies. For the euro area, recessions determined by Model (1a) (i.e. periods for which $z_{t-d} \leq z^{*}$ ) successfully trace out the recession periods, as defined by the Centre for Economic Policy (CEPR). The model also reveals some shorter periods of industrial production contractions at the end of 2001 and 2003 as recessionary. For the USA, Model (1b) traces out the 2001 recession and the Great Recession as defined by the National Bureau of Economic Research (NBER). Additionally, a slack in annual industrial production growth at the end of 2015 and the start of 2016 is also identified as recessionary by Model (1b). 
Although the presented theory suggests nonlinear modelling, testing for (non-)linearity is well advised (see Hubrich \& Teräsvirta, 2013). By performing the Lagrange multiplier test of nonlinearity as developed by Teräsvirta and Yang (2014), the linear model (2) was rejected in favour of a non-linear VAR model. The null of linearity (Model (2)) against the non-linear specification in the form of a smooth transition VAR (STVAR) model was tested. The STVAR model, with the same endogenous set of variables, lag structure and transition variable, was estimated. The null of the linear VAR was rejected against the nonlinear specification (t-statistic $=146.1761$ and $p$-value $=0.0018002$ for the euro area model $(1 \mathrm{a})$; t-statistic $=105.0075$ and $p$-value $=8.7848 \mathrm{e}-06$ for the US model (1b)). We wish to thank Caggiano et al. (2017) for their MATLAB code for the test.

We next present the GIRFs to analyse the relationship between US financial stress $\left(\right.$ ciss $\left._{t}^{U S}\right)$ shocks and the macroeconomic response in the euro area over a horizon of 60 months from the shock. The GIRFs are computed by (3), based on the results of Model (1a). Model (1a) was estimated on four lags, as indicated by Akaike information criteria for Model (2).

The results in Fig. 2 are indicative of inertia in financial stress: once the USA is hit by a financial stress shock, the financial stress level increases afterwards for several months. They also corroborate some earlier findings in the literature revealing that shocks to US financial market stability spill over into the euro area financial system: a positive shock in the US financial stress results in a significant increase in the euro area's financial stress, with only slight differences between the regimes.

While an unexpected increase in the US financial stress is detrimental to the euro area economy under a non-recessionary regime, it

\section{Fig. 2: Response of the euro area to a one standard deviation shock in $\operatorname{ciss}_{t}^{U S}$}

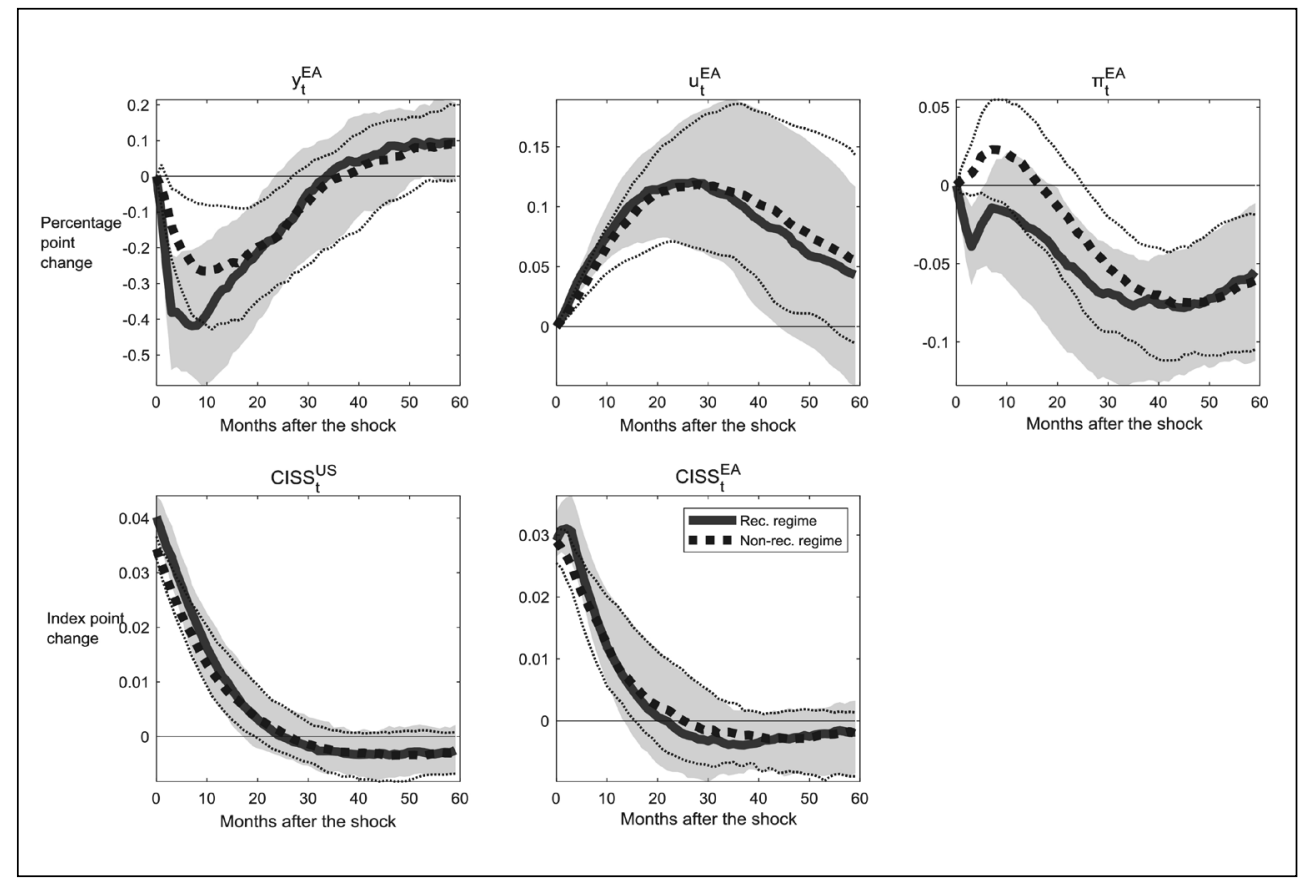

Source: own

Note: Generalized impulse responses to a one standard deviation increase in ciss $_{t}^{U S}$ hitting the euro area in recessionary and non-recessionary periods over a 60 -month horizon. Median responses and the $68 \%$ confidence interval are drawn (dotted lines for a non-recessionary regime and shaded areas for a recessionary regime), as is typical in Bayesian inference analysis, computed from (3), based on the results from (1a). 
even further deepens the euro area recessions. Upon a positive (i.e. increase) one standard deviation shock to the US financial stress, industrial production growth and inflation in the euro area drop (the latter in the long term), while the unemployment rate and the euro area financial stress indicator pick up. In the recessionary regime in the euro area, the response of industrial production is the most pronounced, contracting by up to 0.42 percentage points eight months after the shock. The unemployment rate increases by up to 0.12 percentage points 25-30 months after the shock. The response of inflation is slower and more protracted, reaching the largest effect 37 months after the shock when inflation drops by 0.08 percentage points.

Under a non-recessionary regime in the euro area, the output responds slightly less strongly to the shock, implying non-linearities in the financial stress-business cycle interactions.
Evgenidis and Tsagkanos (2017) and Chen and Semmler (2018) showed that foreign financial stress shocks are more detrimental to domestic industrial output during high than low financial stress regimes. Our results complement their findings by illustrating that the result holds true, not only for the recessionary regime, but also for the non-recessionary regime. The results of the regime-dependent response of inflation to a financial stress shock is also in line with the existing literature on the domestic transmission of financial stress shocks (e.g. Kremer, 2016a).

US financial stress shocks are detrimental to the unemployment rate in the euro area, but the effect seems to be independent of the regime, which is in contrast to the findings reported in the related literature on the effect of uncertainty shocks on unemployment (see, e.g., Caggiano et al. (2017) for US domestic unemployment effects and Caggiano et al.

\section{Fig. 3: Response of the US economy to a one standard deviation shock in $\operatorname{ciss}_{t}^{E A}$}

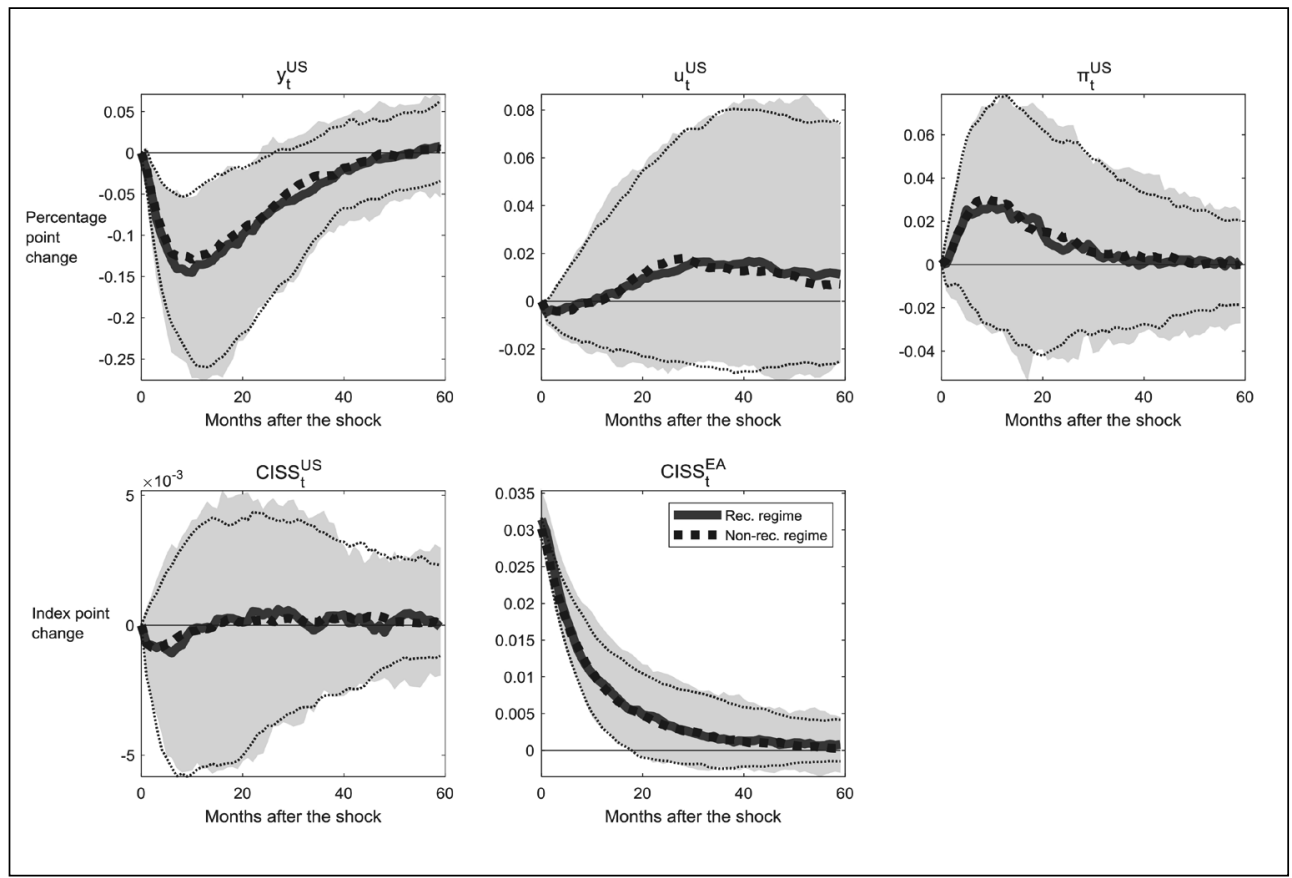

Source: own

Note: Generalized impulse responses to a one standard deviation increase in $\operatorname{ciss}_{t}^{E A}$ hitting the USA in recessionary and non-recessionary period over a 60-month horizon. Median responses and the $68 \%$ confidence interval are drawn (dotted lines for a non-recessionary regime and shaded areas for a recessionary regime), computed from (3), based on results of (1b). 
(2020) for international (Canada and the UK) effects of US uncertainty shocks).

Fig. 3 presents the GIRFs (computed by (3), based on an estimation of Model (1b). Model (1b) was estimated on two lags, indicated by Akaike information criteria for Model (2)) of US variables to a one standard deviation shock to euro area financial stress $\left(\operatorname{ciss}_{t}^{E A}\right)$. There is a stark contrast in the US responses to a financial stress shock, compared to the euro area's response to a US shock. Only the GIRFs for industrial output growth are statistically significant, with a maximum contraction of 0.15 percentage points 11 months after the shock. The effect is not dependent on the regime in the US economy. It is worth noting that the US financial system was isolated from the euro area financial stress shocks during the observed period, as implied by the GIRF for ciss $_{t}^{U S}$.

Overall, the results of the study are indicative of a different transmission of financial stress shocks in the euro area and the USA. We found that the euro area is susceptible to US financial stress shocks. The instabilities in the US financial system affect production in the euro area. The financial shocks deepen euro area recessions, but also lead to a reduction in industrial output growth during non-recessionary periods. Unemployment and inflation follow the business cycle. On the other hand, the stability of the US financial system is not susceptible to the euro area financial stress shocks. However, due to trade ties, financial stress in the euro area can lead to industrial output contraction due to the effect of euro area stress on economic growth in the euro area itself, while the responses concerning US inflation and unemployment are muted.

In contrast, however, the US economy is not immune to domestic financial stress. Fig. 4 shows the effect of a one standard deviation US financial stress shock on the US economy.

The results in Fig. 4 suggest that, in the USA, industrial production and unemployment are susceptible to domestic financial stress shocks, while inflation is not. Differences in regimes can be observed: domestic financial shocks harm the domestic economy more in recessions than during non-recessionary times.

\section{Discussion}

Our results are broadly in line with the existing research. However, beyond the existing literature, they demonstrate the strong international transmission of financial shocks from the USA to the euro area, even under a non-recessionary regime. Therefore, they suggest that policymakers in the euro area and the USA need to carefully monitor financial stress, not only at home but also abroad, as the shocks spread internationally. The global financial crisis and the Great Recession have

\section{Fig. 4: Response of the US economy to a one standard deviation shock in ciss $_{t}^{U S}$}

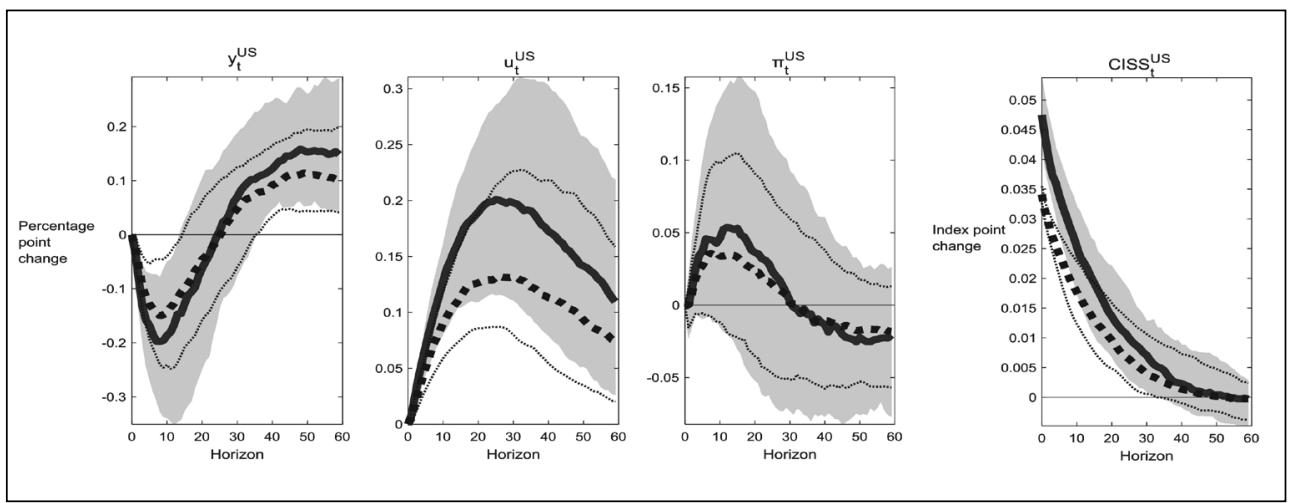

Source: own

Note: Generalized impulse responses to a one standard deviation increase in $\operatorname{ciss}_{t}^{U S}$ hitting the USA in recessionary and non-recessionary periods over a 60 -month horizon. Median responses and the $68 \%$ confidence interval are drawn (dotted lines for a recession regime and shaded areas for a non-recession regime), computed from (3), based on results of (1b). 
shown that both economies are vulnerable to domestic and foreign financial stress shocks. This study, therefore, highlights the importance of the macroprudential supervision of the financial system in the euro area and the USA.

Moreover, our results clearly underscore the importance of coordination in monetary policy between the US and the euro area. While this is relatively less important for the USA, it is crucial for the euro area. In particular, the ECB should pay very close attention to the level of stress in the US financial sector broadly and, more narrowly, across the US financial markets. They are large enough and structured in such a way that their disruption transmits to the euro area and may have very painful consequences for it. Euro area monetary policy should be in a position to react quickly and decisively, in the case of shocks in the euro area and also those that hit the USA, as they will spread to the former. The prolonged effects of the Great Recession in Europe, as compared to the USA, make the point even more poignant.

The euro area continues by building a more structured institutional framework for further integration of the banking sector and, more broadly, financial sector across the continent (Beck, 2012). More integrated European capital and financial markets, as well as banking systems, will, no doubt, be more prone to contagion and easier distribution of financial shocks. Thus, both the architects of the institutions of European financial integration and the agencies charged with oversight and policy decisions cannot ignore the possible effects that originate beyond the area itself.

Besides more extensive banking supervision, the nature and speed of stress shock transmission is likely to be affected by banking consolidation across Europe. The sector has seen substantial changes since the Great Recession (Pohl \& Tortella, 2017). While the restructuring and consolidation of Spanish and Irish banks has largely been completed, developments in troubled Italian and even some major German banks indicate that consolidation has, by no means, been completed and we may expect some further changes.

Similarly, we might expect some changes in the dynamics of financial connections due to Brexit and an adjustment by major financial players to it. Furthermore, trade shocks emanating from protectionist policies could contribute to changes in the transmission of financial shocks. Still, we suspect that our basic insight into American financial dominance and the transmission of US shocks to Europe remains valid, despite these changes, and is here to stay for the foreseeable future.

\section{Conclusions}

We studied the international transmission of shocks to financial stress in the USA and the euro area. Expanding on previous research, we employed five-variable Bayesian TVAR and a data set that included compatible financial stress indices for both studied areas. The methodology endogenously determined the two regimes for industrial production: recessionary and non-recessionary. Our results suggest that the financial stress in the USA transmits internationally under both regimes and contributes to a drop in production and a hike in unemployment in the euro area. Moreover, they confirm that the reaction of production growth, unemployment, inflation and financial stress is regime-dependent and stronger in recessions. In contrast, euro area stress shocks do not affect US variables beyond industrial production, which is most likely due to the trade channel. We suggest that this calls for close coordination of monetary policy in both areas and careful monitoring of financial stress, both at home and abroad.

Acknowledgment: This research has been supported by Slovenia Research Agency (research core funding P5-0023 (A) and BIUS/18-20-024).

\section{References}

Aboura, S., \& van Roye, B. (2017). Financial stress and economic dynamics: The case of France. International Economics, 149, 57-73. https://doi.org/10.1016/j.inteco.2016.11.001

Adam, T., \& Benecká, S. (2013). Financial Stress Spillover and Financial Linkages between the Euro Area and the Czech Republic. Czech Journal of Economics and Finance - Finance a úvěr, 63(1), 46-64.

Alessandri, P., \& Mumtaz, H. (2017). Financial conditions and density forecasts for US output and inflation. Review of Economic Dynamics, 24, 66-78. https://doi.org/10.1016/j.red.2017.01.003

Apostolakis, G., \& Papadopoulos, A. P. (2014). Financial stress spillovers in advanced economies. Journal of International Financial Markets, Institutions \& Money, 32, 128-149. https://doi.org/10.1016/j.intfin.2014.06.001 
Bańbura, M., Giannone, D., \& Reichlin, L. (2010). Large Bayesian vector auto regressions. Journal of Applied Econometrics, 25(1), 71-92. http://dx.doi.org/10.1002/jae.1137

Beck, T. (Ed.). (2012). Banking Union for Europe: Risks and Challenges. London: Centre for Economic Policy Research. Retrieved from https://voxeu.org/sites/default/files/file/Banking_ Union.pdf

Bernanke, B. S., \& Gertler, M. (1989). Agency costs, net worth, and business fluctuations. American Economic Review, Papers and Proceedings, 78(2), 435-439.

Boissay, F., Collard, F., \& Smets, F. (2013). Booms and systemic banking crises (Working Paper Series, No. 1514). Frankfurt am Main: European Central Bank. Retrieved from https://www.ecb. europa.eu/pub/pdf/scpwps/ecbwp1514.pdf

Brunnermeier, M. K., \& Sannikov, Y. (2011). A Macroeconomic Model with Financial Sector. American Economic Review, 104(2), 379-421. http://dx.doi.org/10.1257/aer.104.2.379

Caggiano, G., Castelnuovo, E., \& Figueres, J. M. (2017). Economic Policy Uncertainty and Unemployment in the United States: A Nonlinear Approach. Economics Letters, 151, 31-34. http://dx.doi.org/10.1016/j.econlet.2016.12.002

Caggiano, G., Castelnuovo, E., \& Figueres, J. M. (2020). Economic Policy Uncertainty Spillovers in Booms and Busts. Oxford Bulletin of Economics and Statistics, 82(1), 125-155. https://doi.org/10.1111/obes.12323

Caggiano, G., Castelnuovo, E., \& Groshenny, N. (2014). Uncertainty Shocks and Unemployment Dynamics in U. S. Recessions. Journal of Monetary Economics, 67, 78-92. http://dx.doi.org/10.1016/j.jmoneco.2014.07.006

Chatterjee, S., Chiu, C.-W., Hacioglu Hoke, S., \& Duprey, T. (2017). A financial stress index for the United Kingdom (Staff Working Paper No. 697). London: Bank of England. https://dx.doi. org/10.2139/ssrn.3085789

Chen, C. W. S., \& Lee, J. C. (1995). Bayesian inference of threshold autoregressive models. Journal of Time Series Analysis, 16(5), 483-492. http://dx.doi.org/10.1111/j.1467-9892.1995. tb00248.x

Chen, P., \& Semmler, W. (2014). Financial Stress, Regime Switching and Macrodynamics: Theory and Empirics for the US, EU and Non-EU Countries. Economics, 8(20), 1-42. http://dx.doi.org/10.5018/economics-ejournal. ja.2014-20

Chen, P., \& Semmler, W. (2018). Financial stress, regime switching and spillover effects: Evidence from a multi-regime global VAR model. Journal of Economic Dynamics \&
Control, 91, 318-348. http://dx.doi.org/10.1016/j. jedc.2018.03.001

Claessens, S., Kose, M. A., \& Terrones, M. E. (2012). How do business and financial cycles interact? Journal of International Economics, 87(1), 178-190. http://dx.doi.org/10.1016/j. jinteco.2011.11.008

Dovern, J., \& van Roye, B. (2014). International transmission and business-cycle effects of financial stress. Journal of Financial Stability, 13, 1-17. http://dx.doi.org/10.1016/j.jfs.2014.02.006

ECB. (2016). Financial Stability Review, November 2016. Frankfurt: European Central Bank. Retrieved March 5, 2019, from https://www.ecb.europa.eu/pub/pdf/fsr/ financialstabilityreview201611.en.pdf

ECB. (2019). Statistical Data Warehouse, Systemic Stress Composite Indicator. Retrieved February 25, 2019, from https://sdw.ecb.europa.eu/

Eickmeier, S., \& Ng, T. (2015). How Do US Credit Supply Shocks Propagate Internationally? A GVAR Approach. European Economic Review, 74, 128-145. https://doi.org/10.1016/j. euroecorev.2014.11.011

Evgenidis, A., \& Tagkanos, A. (2017). Asymmetric effects of the international transmission of US financial stress. A thresholdVAR approach. International Review of Financial Analysis, 51, 69-81. http://dx.doi.org/10.1016/j. irfa.2017.03.003

Eurostat. (2019). Unemployment by sex and age - monthly average. Retrieved March 4, 2019, from https://appsso.eurostat.ec.europa.eu/nui/ show.do?dataset=une_rt_m\&lang=en

Fontaine, L., Didier, L., \& Razafindravaosolonirina, J. (2017). Foreign policy uncertainty shock ands and the US macroeconomic activity: Evidence from China. Economics Letters, 155, 121-125. https://doi. org/10.1016/j.econlet.2017.03.034

Gertler, M., \& Kiyotaki, N. (2010). Financial Intermediation and Credit Policy in Business Cycle Analysis. Handbook of Monetary Economics, 3, 547-599. http://dx.doi.org/10.1016/B978-0-44453238-1.00011-9

Gertler, M., Gilchrist, S., \& Natalucci, F. (2007). External constraints on monetary policy and the financial accelerator. Journal of Money, Credit and Banking, 39(2-3), 295-330. http:// dx.doi.org/10.1111/j.0022-2879.2007.00027.x

Gilchrist, S., \& Zakrajsek, E. (2012). Credit spreads and business cycle fluctuations. The American Economic Review, 102(4), 1692-1720. http://dx.doi.org/10.1257/aer.102.4.1692

$\mathrm{Ha}$, J., Kose, M. A., Otrok, C., \& Prasad, E. S. (2017). Global Macro-Financial Cycles and Spillovers. Paper presented at the 18th 
Jacques Polak Annual Research Conference, IMF, November 2-3, Washington DC. Retrieved February 22, 2019, from https://www.imf.org/en/ News/Seminars/Conferences/2017/09/18/2017eighteenth-annual-research-conference

Hakkio, C. S., \& Keeton, W. R. (2009). Financial stress: what is it, how can it be measured, and why does it matter? Economic Policy, 94(2), 5-50.

Hartmann, P., Hubrich, K., Kremer, M., \& Tetlow, R. J. (2013). Melting down: Systemic financial instability and the macroeconomy. Annual Conference 2013 (Duesseldorf): Competition Policy and Regulation in a Global Economic Order 80487, Verein für Socialpolitik/ German Economic Association. Retrieved February 25, 2019, from https://www.econstor.eu/ bitstream/10419/80487/1/NfS_2013_pid_458.pdf

Helbling, T., Huidrom, R., Kose, M. A., \& Otrok, C. (2011). Do credit shocks matter? A global perspective. European Economic Review, 55(3), 340-353. http://dx.doi.org/10.1016/j. euroecorev.2010.12.009

Holló, D., Kremer, M., \& Lo Duca, M. (2012). CISS - A Composite Indicator of Systemic Stress in the Financial System (Working Paper Series, No. 1426). Frankfurt am Main: European Central Bank. Retrieved from https://www.ecb.europa.eu/ pub/pdf/scpwps/ecbwp1426.pdf

Huang, Z., Tong, C., Qiu, H., \& Shen, Y. (2018). The spillover of macroeconomic uncertainty between the U. S. and China. Economics Letters, 171, 123-127. http://dx.doi. org/10.1016/j.econlet.2018.07.018

Hubrich, K., \& Teräsvirta, T. (2013). Thresholds and Smooth Transitions in Vector Autoregressive Models. In T. B. Fomby, L. Kilian, \& A. Murphy (Eds.), VAR Models in Macroeconomics - New Developments and Applications: Essays in Honor of Christopher A. Sims (Advances in Econometrics, Vol. 32) (pp. 273-326). Bingley: Emerald Group Publishing Limited.

Hubrich, K., \& Tetlow, R. J. (2015). Financial stress and economic dynamics: The transmission of crises. Journal of Monetary Economics, 70, 100 115. http://dx.doi.org/10.1016/j.jmoneco.2014.09.005

Kiyotaki, N., \& Moore, J. (1997). Credit cycles. Journal of Political Economy, 105(2), 211-248. http://dx.doi.org/10.1086/262072

Kliesen, K. L., Owyang, M. T., \& Vermann, E. K. (2012). Disentangling diverse measures: a survey of financial stress indexes. Review, Federal Reserve Bank of St. Louis, 94(5), 369-398. http://dx.doi.org/10.20955/r.94.369-398

Koop, G., \& Potter, S. M. (1999). Dynamic Asymmetries in U. S. Unemployment. Journal of Business and Economic Statistics, 17(3), 298-
312. http://dx.doi.org/10.1080/07350015.1999.10 524819

Koop, G., Pesaran, M. H., \& Potter, S. M. (1996). Impulse response analysis in nonlinear multivariate models. Journal of Econometrics, 74(1), 119-147. http://dx.doi.org/10.1016/03044076(95)01753-4

Kremer, M. (2016a). Macroeconomic effects of financial stress and the role of monetary policy: a VAR analysis for the euro area. International Economics and Economic Policy, 13(1), 105-138. http://dx.doi.org/10.1007/s10368-015-0325-z

Kremer, M. (2016b). Financial stress indices: An introduction. Spanish Economic Review, 14(1), 1-4. http://dx.doi.org/10.1016/j.srfe.2016.02.001

Kwon, Y. (2003). Bayesian Analysis of Threshold Autoregressive Models (Doctoral dissertation). University of Tennessee, Knoxville.

Mittnik, S., \& Semmler, W. (2012). Estimating a Banking-Macro model for Europe Using a MultiRegime VAR. Amsterdam: SSRN. https://dx.doi. org/10.2139/ssrn.2012106

Mittnik, S., \& Semmler, W. (2013). The real consequences of financial stress. Journal of Economic Dynamics \& Control, 37(8), 1479-1499. http://dx.doi.org/10.1016/j.jedc.2013.04.014

Morley, J., \& Piger, J. (2012). The Asymmetric Business Cycle. Review of Economics and Statistics, 94(1), 208-221. http://dx.doi. org/10.1162/REST_a_00169

OECD. (2019a). Production and sales (MEI). Retrieved February 27, 2019, from https://stats. oecd.org/Index.aspx?DataSetCode=MEI_REAL\#

OECD. (2019b). Consumer price indices (CPIs) - Complete database. Retrieved February 27, 2019, from https://stats.oecd.org/Index. aspx?DataSetCode=PRICES_CPI\#

Pohl, M., \& Tortella, T. (2017). A Century of Banking Consolidation in Europe: The History and Archives of Mergers and Acquisitions. London: Routledge. http://dx.doi. org/10.4324/9781315264028

Schleer, F., \& Semmler, W. (2014). Financial Sector and Output Dynamics in the Euro Area: Non-linearities Reconsidered. Journal of Macroeconomics, 46, 235-263. http://dx.doi. org/10.1016/j.jmacro.2015.09.002

Sims, C. A., \& Zha, T. (1998). Bayesian methods for dynamic multivariate models. International Economic Review, 39(4), 949-968. http://dx.doi.org/10.2307/2527347

Teräsvirta, T., \& Yang, Y. (2014). Linearity and Misspecification Tests for Vector Smooth Transition Regression Model (CREATES Research Papers, 2014-04). Aarhus: Aarhus University. Retrieved from ftp://ftp.econ.au.dk/ creates/rp/14/rp14_04.pdf 